\title{
Predictive Mapping of Soil Properties for Precision Agriculture Using Geographic Information System (GIS) Based Geostatistics Models
}

\author{
John Kingsley ${ }^{1}$, Solomon Odafe Lawani ${ }^{2}$, Ayito Okon Esther ${ }^{3}$, Kebonye Michael Ndiye ${ }^{1}$, Ogeh Joseph Sunday ${ }^{2}$ \\ \& Vít Penížek ${ }^{1}$ \\ ${ }^{1}$ Department of Soil Science and Soil Protection, Faculty of Agrobiology, Food, and Natural Resources, Czech \\ University of Life Sciences, Prague, Czech Republic \\ ${ }^{2}$ Department of Soil Science and Land Management, Faculty of Agriculture, University of Benin, Edo State, \\ Nigeria. \\ ${ }^{3}$ Department of Soil Science, Faculty of Agriculture, University of Calabar, Cross River State, Nigeria. \\ Correspondence: John Kingsley, Department of Soil Science and Soil Protection, Faculty of Agrobiology, Food, \\ and Natural Resources, Czech University of Life Sciences, Kamycka 129,16500, Prague, Czech Republic. \\ E-mail: Johnkingsley0107@gmail.com
}

Received: June 19, 2019

doi:10.5539/mas.v13n10p60
Accepted: September 16, 2019

Online Published: September 17, 2019

\begin{abstract}
In precision Agriculture, geostatistical methods as a predictive tool have been extensively utilized. The approach estimates soil properties spatial variability and dependency. This study was carried out in Ovia north east Local Government Area of Edo State of Nigeria in order to map soil properties (Sand, Clay, pH, OC, P, N and CEC) and redict their spatial variability. Twenty-nine (29) soil samples were collected randomly from Typic Kandiudults soil type under three different land use, teak forest plantation, shrub, and arable farm. The soil samples were air-dried and passed through a $2 \mathrm{~mm}$ sieve before being analyzed for $\mathrm{pH}\left(\mathrm{CaCl}_{2}\right), \mathrm{SOC}$, Sand, Clay, Phosphorus, Nitrogen, and CEC. Generated data were statistically and geostatistically computed to explain the spatial variability of soil properties. The traditional method of soil analysis and interpretation are tedious, time-consuming with escalating budgets thus geostatical approach. Available phosphorus yielded large variability with $\mathrm{CV}=57.08 \%$ followed by clay content with $\mathrm{CV}=49.03 \%$. Spherical, Gaussian, Hole Effect model, Stable, Exponential and Circular models were fitted for all the soil parameters. The result revealed that soil $\mathrm{pH}$, Sand content, TN and CEC were moderate spatially autocorrelated with nugget/sill value of $0.32,0.21,0.49$ and 0.30 respectively. SOC also gave a moderate spatially autocorrelated with nugget/sill value of 0.44 . And Clay and Available phosphorus were strong spatially autocorrelated with nugget/sill value of 0.15 and 0.13 respectively. Cross-validation of the output maps using the semivariogram showed that the interpolation models are superior to assuming mean for any unsampled area. The output maps will help soil users within the area to proffer best management technology to improve crop, fiber and water production.
\end{abstract}

Keywords: precision agriculture, geostatistics, geographic information system, soil properties, ordinary kriging, landuse

\section{Introduction}

The soil ecosystem is a complex one which is formed from different weathering process of rock materials. It is composed of mineral and organic fractions, yielding specific physical, chemical, mineralogical and biological properties (Esu, 2005, Kingsley et al., 2019, Akpan-Idiok et al., 2012). These properties are also influenced by different environmental covariates such as micro-climatic, topography, geology, biological organisms and among others (Shukla, 2009; Jenny, 1941; Esu, 2005) leading to their spatial difference across the small land area (Townsend, Vitousek, \& Trumbare, 1995). Therefore, soil mapping is essential. Soil mapping, on the other hand, is the process of gathering, describing, manipulating, classifying and predicting soil properties (Esu,2005). It also provides up-to-date information in terms of landforms, terraces, and vegetation (Denton et al., 2017; Brown et al., 1978). Importantly, these updated soil inventories are reliable in policy and decision making under precision agriculture (Denton et al., 2017). 
In the past 20 years, so much have been achieved as regards to the approaches towards soil mapping (Goovaerts, 1999; Mcbratney et al., 2000 Pravat et al., 2016, Denton et al., 2017). Conventional soil mapping which happened to be a tedious method of gathering information about the soil resources by soil mappers have been improved with great advances in spatial science (Esu et al., 2005, Fasina et al., 2012)

In traditional soil mapping, a representative soil property from a given location is used to describe a soil unit, which is then vectorized using physiographic and landforms methods in the soil map. However, the soil mappers are fully aware that the spatial variability of the soil properties is not represented as they are distorted by boundaries (Heuvelink and Webster 2001). But in reality, the soil properties are spatially variable and shows a continuum, and for accurate prediction, this property should be considered. The traditional method of soil analysis and interpretation are tedious, time-consuming with escalating budgets. On the other hand, geostatistical methods are some packages in ArcGIS and other software alike are widely accepted as an important spatial interpolation method in land resource inventories (Pravat et al., 2016, Hengl et al., 2004; Bhunia et al., 2016). Geostatistics methods (Kriging, Inverse Distance Weighting, Spline) are widely employed as important spatial interpolation techniques in soil mapping. (Hengl et al., 2004; Bhunia et al., 2016, \& Ofem et al., 2017). Although, Weller et al., 2002 reported a better interpolation result with Kriging than any other method. It is also commonly used as a predictive tool (Franzen \& peck, 1995). Furthermore, the approach engages expert knowledge in making an accurate prediction of soil properties(Lin et al. 2005; Shibu et al. 2006).

Geostatistics techniques estimate the spatial variability using variogram models which predicts the values of soil properties at un-sampled locations (Pravat et al., 2016; Goovaerts, 1998 \&1999; Denton et al., 2016; Gouri et al., 2018 and Ofem et al., 2017). These methods are widely used to assess spatial correlation in soils and ascertain the spatial variability in soil properties (physical, chemical and biological) as opined by Gouri et al., 2018. Kriging engages the mean of a known location to determine the property of value in the unsampled area, which will narrow the section of estimation to the highest degree (Penížek \& Borůvka, 2006).

In Nigeria, all the soil maps available were prepared through conventional survey and very little effort have been made so far in modern spatial mapping techniques (Denton et al., 2016 and Ofem et al., 2017). The accurate prediction of soil properties variability (particle size distribution, $\mathrm{pH}$ organic carbon, CEC, ECEC, Available phosphorus among others) is essential in sustainable agriculture and it accounts as one of the fundamentals for soil users. Therefore, the objective of this study was to map soil properties (Sand, Clay, pH, OC, P, N and CEC) and predict their spatial variability using the geostatistical technique.

\section{Materials and Methods}

\subsection{Study Area}

The research was conducted in Odighi area of Ovia North East, Edo State in Nigeria stretching between $6^{\circ} 37^{\prime} 5.24^{\prime \prime} \mathrm{N}-6^{\circ} 36^{\prime} 46.97 " \mathrm{~N}$ latitude and $5^{\circ} 45^{\prime} 53.88^{\prime \prime} \mathrm{E}-5^{\circ} 45^{\prime} 49.16^{\prime \prime E}$ longitude encompassing the area of $3 \mathrm{~km}^{2}$ (Fig. 1). The vegetation of the study area is a multistoried high tropical rainforest characterized majorly by teak. The area is characterized by strongly undulating terrain with a gentle slope at the crest and valley slope. Geologically, the soils are derived from materials of tertiary coastal plain deposits and are made up of continental sand and sandstone with shale and are classified according USDA Soil Taxonomy classification as Typic kandiudlts (Imadojemu et al., 2018). Average annual rainfall pattern of the location varied between $1500-2500 \mathrm{~mm}$ in a bimodal form with two peaks in June and September and a peak fall referred to as August break (NIFOR, 2013). The monthly minimum and maximum temperature vary between $25^{\circ} \mathrm{C}$ and $31^{\circ} \mathrm{C}$, during the wet and dry period of the year. The relative humidity varies from 80 percent during the rains to about $60 \%$ in the dry season (NIFOR, 2013).

\subsection{Field Sampling and Laboratory Analysis}

A total of 29 samples were randomly collected from three selected land-use of the study location. These include 8 auger points from a shrub farm, 12 observation points from a teak forest and 9 auger points from an arable farm. Samples were collected at a depth of $0-20 \mathrm{~cm}$ for fertility purpose with the help of hand-held global positioning system (GPS).

Soil samples obtained were air-dried and pass through a 2-mm sieve and used for particle size analysis using Boyocouos hydrometer method (Bouyoucos, 1962; Van Reeuwijk, 1992). The pH of the soils was analyzed potentiometrically using a glass-calomel combination electrode (Van Reeuwijk, 1992); Organic carbon was determined by the Walkley and Black (1934) method. Available soil P was analyzed according to the standard procedure of Olsen et al. (1954) extraction method. Total $\mathrm{N}$ was analyzed using the Kjeldahl digestion, 
distillation, and titration method as described by Black (1965). Cation exchange capacity (CEC) was determined using flame photometer as described by (Chapman, 1965).

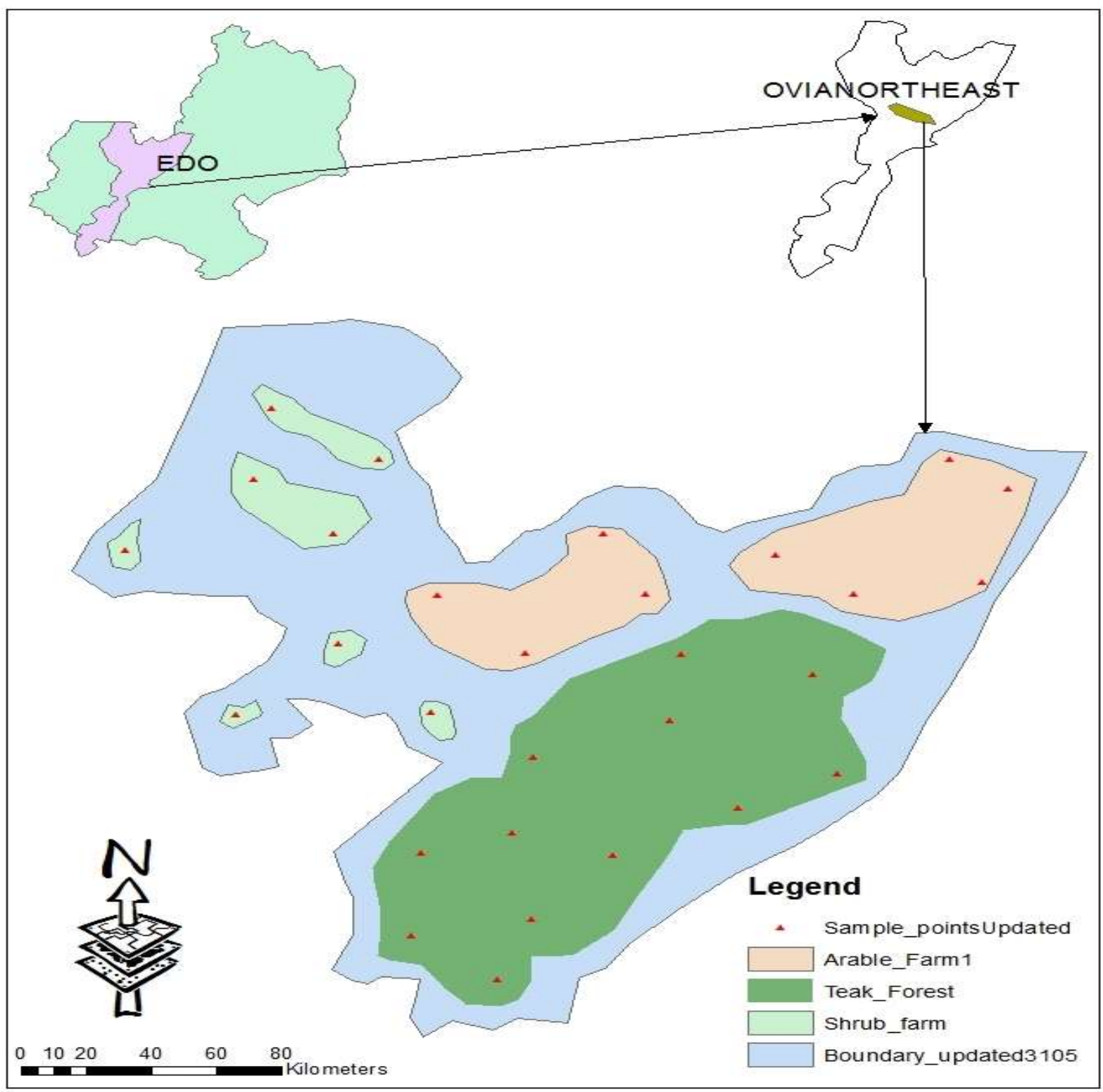

Figure 1. Location and sampling points map of the study area

\subsection{Geostatistical Model in GIS}

Soil spatial prediction and GIS approach were engaged to produce predictive maps of the soil properties under study. The software used for the research was ArcGIS 10.6 (ESRI Co, Redlands, US). The software package known as spatial analyst tool was activated to carry out the interpolation process, to predict spatial dependency and spatial variability of the soil properties under investigation. Meanwhile in the spatial tool analyst is the geostatistical model known as Ordinary kriging (OK), and was used in the study. "The model utilizes measured for prediction of the values of the unmeasured sites (un-samples locations) $\mathrm{X}_{0}$ by assuming the $\mathrm{z}^{*}\left(\mathrm{X}_{0}\right)$ equals the line some of the known measured value (field measured value). The model can express spatial variation and allow a variety of map outputs, and at the same time minimize the errors of predicted values (González et al. 2014)".

Kriging models as follows (Wang et al. 2009):

$$
Z^{*}\left(X_{0}\right)=\sum_{i=1}^{n} \lambda_{i} z_{i}
$$

Where $\mathrm{Z}^{*}\left(\mathrm{X}_{0}\right)$ is the predicted value at position $\mathrm{X}_{0}, \mathrm{Z}\left(\mathrm{X}_{\mathrm{i}}\right)$ the known value at sampling site $\mathrm{X}_{\mathrm{i}}, \lambda_{\mathrm{i}}$ the weighting coefficient of the measured site and $\mathrm{n}$ is the number of sites within the neighborhood searched for the interpolation. 
In kriging, a semivariogram model is also used to define the weights of the function as pointed out by Webster \& Oliver (2001), and the semivariance is an autocorrelation statistic (Mabit \& Bernard 2007). It is used as a basic tool to evaluate the spatial distribution structure of the soil properties with reference to regionalized variable theory and intrinsic hypotheses (Nielsen and Wendroth 2003), a semivariogram is expressed as:

$$
\gamma(h)=\frac{1}{2 N(h)} \sum_{i=1}^{n}\left[Z\left(X_{i}-Z\left(X_{i}+h\right)\right]^{2}\right.
$$

where $\gamma(\mathrm{h})$ is the semivariance, $\mathrm{h}$ the lag distance, $\mathrm{Z}$ the parameter of the soil property, $\mathrm{N}(\mathrm{h})$ the number of pairs of locations separated by a lag distance $h, Z(x i)$, and $Z\left(X_{i}+h\right)$ are values of $Z$ at positions xi and $x i+h(W a n g$ and Shao 2013).

After the semivariogram computation, the models suitable were Gaussian, spherical, linear and exponential). The empirical semivariograms generated from the data were fitted by theoretical semivariogram models to yield geostatistical parameters, including nugget variance $\left(\mathrm{C}_{0}\right)$, variance $\left(\mathrm{C}_{1}\right)$, sill $\left(\mathrm{C}_{0}+\mathrm{C}_{1}\right)$, and range $(\mathrm{k})$. The nugget/sill ratio, $\mathrm{C}_{0} /\left(\mathrm{C}_{0} / \mathrm{C}_{1}\right)$, was computed to characterize the spatial dependency of the values. In addition, a nugget/sill ratio $<25 \%=$ strong spatial dependency, $25-75 \%=$ moderate spatial autocorrelation and $>75 \%$ shows weak spatial dependency; otherwise, the spatial dependency is moderate (Cambardella et al. 1994).

Accuracy assessment

\subsection{Cross Validation}

This "model validation technique is used in assessing how the results of the statistical analysis will generalize to an independent data set. Cross-validation technique was adopted for evaluating and comparing the performance of ordinary kriging interpolation method. The sample points were arbitrarily divided into two datasets, with one estimate mean value against measured mean were engaged in order to validate the model. The root means square error (RMSE) is error based measures to evaluate the accuracy of interpolation methods. RMSS must be close to 1 (Johnston, Hoef, Krivoruchko, \& Lucas, 2001)".

$$
\text { RMSE }=\sqrt{\frac{\sum_{i=1}^{N}\left(0_{i}+Z_{i}\right)^{2}}{N}}
$$

\section{Results}

\subsection{Descriptive Statistics of the Soil Properties}

The summary of the descriptive statistical analysis of Soil pH, Soil organic carbon (SOC), Sand fractions, Clay content, Available phosphorus, Total nitrogen, and Cation exchange capacity is presented in Table 1.

Table 1. Descriptive statistical analysis for the soil properties under investigation

\begin{tabular}{ccccccccc}
\hline Variables & Mean & Min & Max & Std.Dev. & Coef.Var. & Skewness & Kurtosis & $\begin{array}{c}\text { Distribution } \\
\text { Pattern }\end{array}$ \\
\hline Soil pH & 4.0 & 3.2 & 4.7 & 0.42 & 10.52 & 0.002 & -0.894 & Normal \\
SOC & 1.1 & 0.2 & 3.1 & 0.33 & 30.00 & 0.414 & -1.088 & Log \\
Sand & 826.5 & 700 & 954 & 78.94 & 9.55 & 0.196 & -0.992 & Normal \\
Clay & 154.3 & 34 & 280 & 75.66 & 49.03 & -0.101 & -1.083 & Normal \\
Avail. P & 9.1 & 2.8 & 19.8 & 5.20 & 57.08 & 0.576 & -0.474 & Normal \\
N & 25.5 & 12.2 & 44.6 & 8.74 & 34.22 & 0.429 & -0.350 & Normal \\
CEC & 1.5 & 1.0 & 2.3 & 0.36 & 23.55 & 0.305 & -0.815 & Normal \\
\hline
\end{tabular}

The means of the parameters were 4, 1.1, 826.5, 154.3, 9.1, 25.5 and 1.5 for pH, SOC, Sand, Clay, Available Phosphorus, Nitrogen and Cation exchange capacity respectively. The sand fractions gave the highest standard deviation $(78.94 \mathrm{~g} / \mathrm{kg})$ while the soil organic carbon gave the lowest $(0.33 \mathrm{~g} / \mathrm{kg})$. Soil organic carbon, Clay, Available phosphorus and total nitrogen gave the highest coefficient of variation of between $30-60 \%$. The soil parameters gave a positive skewness except for clay fraction which was negatively skewed. The soil properties were normally distributed except for soil carbon which was log transformed to removed outliers. This was carried out to yield a more reliable output (Reza et al., 2015).

\subsection{Geostatistics Models of the Soil Properties}

Inasmuch as the descriptive analysis result gave a vital output of the soils under investigation but they could not describe the spatial variability and autocorrelation of the soil the property. Hence geostatistic modeling was 
adopted to interpret spatial variability pattern of the soils (Table 2). The results of the geostatistic interpolation of the soil properties are presented in Table 2, Fig. 1 and Fig.2. These result revealed the spatial variability of the soil properties.

Table 2. Geostatistical models for the soil properties

\begin{tabular}{cccccccc}
\hline Variables & $\begin{array}{c}\text { Fitted } \\
\text { model }\end{array}$ & Nugget & Sill & Range $^{*}$ & $\begin{array}{c}\text { Nugget/Nugget+Sill } \\
\text { Spatial } \\
\text { class }\end{array}$ & RMSE $^{* *}$ \\
\hline Soil pH & Spherical & 0.134 & 0.283 & 0.2 & 0.32 & Moderate & 1.082 \\
SOC & Spherical & 0.595 & 0.435 & 0.6 & 0.44 & Moderate & 1.025 \\
Sand & Gaussian & 1542.8 & 5912.7 & 0.1 & 0.21 & Moderate & 1.144 \\
Clay & Hole Effect & 742.8 & 4955.2 & 0.8 & 0.13 & Strong & 1.184 \\
Available $\quad$ P & Stable & 4.7 & 25.9 & 0.8 & 0.15 & Strong & 1.050 \\
Nitrogen & Exponential & 47.954 & 34.658 & 0.1 & 0.49 & Strong & 1.049 \\
CEC & Circular & 0.0494 & 0.116 & 0.1 & 0.30 & Moderate & 0.942 \\
\hline
\end{tabular}

In the semivariogram model $\mathrm{pH}$ and soil organic carbon followed a spherical model; sand=Gaussian model, Clay=Hole Effect Model; Available phosphorus= Stable model; Nitrogen= Exponential model and $\mathrm{CEC}=$ Circular model. The nugget/sill ratio of soil $\mathrm{pH}$, SOC, Sand, Clay, available $\mathrm{P}$, nitrogen and CEC were $0.32,0.44,0.21,0.13,0.15,0.49$ and 0.30 respectively. The RMSE revealed the steadiness of the predicted values and the acceptable precision respectively, as it shows the suitability of the predicted models by ordinary kriging approach.

\section{Discussion}

There is so much variation in the clay, available phosphorus, and total nitrogen parameters and little variation in soil $\mathrm{pH}$ and sand content. The result obtained in this study is similar to the report by Denton et al., 2016 \& Reza et al., 2015. But contradicts the Reza et al., 2015 in the sand content CV. Similarly, the high mean value obtained in the sand content may have been contributed by a large number of point data with high sand content, this also raised the standard deviation. This type of soil may encourage the leaching of basic cations especially in the period of high rainfall regime (Ofem et al., 2017, Kingsley et al., 2019). Also, the low coefficient of variation for $\mathrm{pH}$ was influenced by land use, parent materials, climate among others (Denton et al., 2016, Akpan-Idiok et al., 2012, Ofem et al., 2017) and gave a spatial variability in the three different land use.

The continuous variability that exists in the soil ecosystem is influenced by several environmental covariates, mass movement, soil creep, hydrology, and landforms. In addition, soil properties under different land uses can also be influenced by micro-climate and litterfall in forest land; irrigation, fertilization, or drainage pattern in arable farms (Moasheri \& Foroughifar, 2013). These factors have influences on the data distribution pattern.

The spatial interpolation of the soil properties, soil $\mathrm{pH}, \mathrm{SOC}$, sand, clay, available phosphorus, total nitrogen, and CEC was carried out using ordinary kriging method (Fig.1). This technique was adopted to transform point soil observations into continuum variables. The predictive maps of soil properties $(\mathrm{pH}, \quad \mathrm{SOC}, \mathrm{Sand}, \mathrm{Clay}, \mathrm{P}, \mathrm{N}$, and CEC) revealed the concentration of high $\mathrm{pH}$ values in teak forest land and low $\mathrm{pH}$ value in the arable farm. This may be as a result of slow degradation of litterfall and yielding low organic matter turnover for teak forest and the application urea fertilizers for the arable farm. Although the general low $\mathrm{pH}(<5.0)$ value in all the land use may be a structural factor (parent material and climate). Soil organic carbon was high in the teak forest land use as expected. While the lowest SOC value was obtained in the shrub farm. This may be caused by a lack of organic matter turnover by excessive animal grazing in the region. High sand content was concentrated in the southern region (teak forest). This result collaborates with that of Akamigbo, 1984. High clay distribution was obtained in the northeastern (arable farm) part of the area under study. This may be attributed to the structural factor like land denudation (Kerry, 2012). Also, well-reflected changes were observed in the spatial distribution for Available P, Nitrogen, and CEC. Although high spatial distribution of phosphorus, nitrogen, and CEC was observed in the teak forest which is in the south direction of the area. The result obtained suggests the engagement of certain land management practices such as the use of biochar, minimum tillage, fallow system. This will, in turn, increase carbon in the other parts of the land.

Using the ordinary kriging, maps for each soil property was plotted based on the semivariogram fitness models of cross validation (Fig 3). The model with the best fit were fitted into all the parameters as thus: 


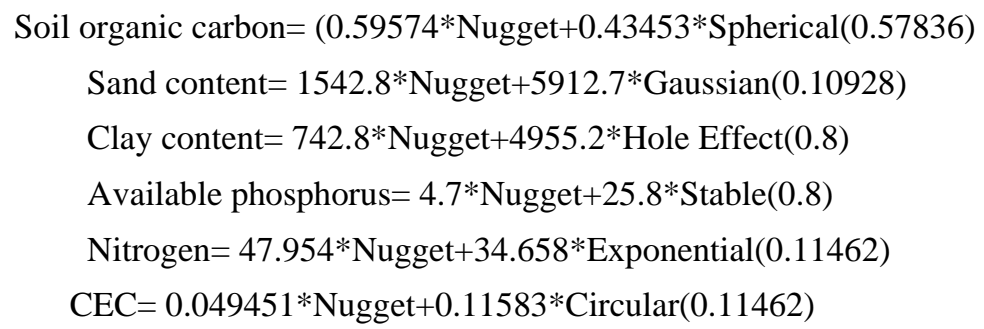

Fig. 2 showed the selected semivariogram models of fitness plots. The nugget effects are accredited to either laboratory measurement errors or spatial dependency errors at varying points smaller than the sampling ranges or both. Lag distance is a distance beyond which the samples do not affect each other or do not show enough dependence and the spatial points can be considered independently of each other.

The nugget/sill ratio may be low or high. High nugget/sill ratio reveals that the spatial distribution is influenced by stochastic factors such as cropping system, soil amendments usage and other human factors. While low nugget/sill ratio indicates structural dependency such as parent material, biological organism, relief and other natural factors that influence soil spatial variability. Soil $\mathrm{pH}$ gave moderate spatial autocorrelation $(0.25-0.75)$ and SOC gave a weak spatial autocorrelation $(>0.75)$. Sand content yielded a moderate spatial autocorrelation which collaborates with the results by (Reza et al., 2015, Safari et al., 2013). Clay content and Available phosphorus were strongly spatial autocorrelated $(<0.25)$. But a high nugget effect was obtained in Nitrogen semivariogram plot contradicts the result by Denton et al., 2017. CEC yielded moderate spatial autocorrelation (0.25-0.75). Therefore, the strong spatial autocorrelation was obtained in clay and available phosphorus could be attributed to structural elements. While the moderate and weak spatial autocorrelation in other soil property (pH, SOC, Sand, nitrogen, and CEC) may have been developed from random factors such as poor land conservation approach, chemical fertilizer application, uncontrolled grazing amongs others. Furthermore, the decrease of the soil heterogeneity across the three different land use may have been influenced by human activities, drainage, fertilization among others, these reduce spatial correlation (Gouri et al., 2018).

\section{Conclusion}

In this study, 29 samples were collected from three different land use (teak forest, arable and shrub farms) and were used to evaluate soil spatial distribution. The geostatistics models in GIS which were adopted in this study proved essential for evaluation of different land use inventories in various status. The six (6) geostatistical interpolation models were fitted for seven (7) soil properties (Soil pH, SOC, Sand, Clay, Available Phosphorus, Total Nitrogen and CEC). The soil $\mathrm{pH}$ and sand content did not vary that much in all the three land uses as these were referenced to stochastic factors. The spatial distribution of SOC and total N, Phosphorus and CEC were greatly influenced by the land use. As per the transformation of forest land to arable or shrubs results to a reduction in biomass accumulation which affects organic matter content and in turn, SOC. The output from our study indicates the spatial distribution of soil parameters and the observation points distance in this research is adequate for predictive modeling. This approach is important for precision agriculture and environmental modeling.

The result from this study also showed that the soil properties in the three different land use are variable and heterogenous hence the spatial distribution and dependency within the same area under investigation. This also validates the relevance of GIS methods in predictive mapping. Cross validation of the semivariogram models generated the ordinary kriging geostatistical revealed that predictive mapping is superior to guessing the mean of the observed points at any unsampled location.

The result from this research puts a value on geostatistic interpolation as a useful guide for Soil Scientist within Southern Nigeria in improving soil maps resolution with detailed information. In addition, the result of this study can help profer suitable crop management technology to be adopted by small farm holders in increasing crop, fiber, and water production. Concluding, the enhancement of regional soil maps using this approach using more point data is strongly recommended.

\section{References}

Akamigbo, F. O. R. (1984). The accuracy of field textures in humid tropical environment. Soil Survey and Land Evaluation, 493, 63-70.

Akpan-Idiok, A. U \& Ukwang, E. E. (2012). Characterization and Classification of Coastal Plain Soils in Calabar, Nigeria. Journal of Agricultural Biotechnology and Ecology, 5(3), 19-33. 
Akpan-Idiok, A. U. (2012). Physico-chemical properties, degradation rate and vulnerability potential of soils formed on coastal plain sands in Southeast, Nigerian Journal of Agricultural Research, 7(7), 358-366.https://doi.org/10.3923/ijar.2012.358.366

Bhunia GS, Shit PK, Maiti R (2016). Comparison of GIS-based interpolation methods for spatial distribution of soil organic carbon (SOC). Journal Saudi Society Agriculture Science. https://doi.org/10.1016/j.jssas.2016.02.001

Black, C.A., Evans, D.D., Ensminger, L.E. White, J.L. \& Clark, F.E. (1965). Method of Soil Analysis Part2 Chemical and Microbiological Properties. American Society of Agronomy, Wisconsin, USA. 1571 p.

Bouyoucos, G.J. (1962). Hydrometer method improvement for making particle size analysis of soils. Agronomy Journal, 54, 179-186https://doi.org/10.2134/agronj1962.00021962005400050028x

Brown, G., Newman, A. C. D., Rayner, J. H. \& Weir, A. H. (1978). The structure and chemistry of soil clay minerals In D. J. Greenland \& M. H. B. Hayes (Eds.), The chemistry of soil constituents, 29178. New York, NY, Wiley.

Cambardella, C., Moorman, T., Parkin, T., Karlen, D., Novak, J., Turco, R. \& Konopka, A. (1994). Field-scale variability of soil properties in central Iowa soils. Soil Science Society of America Journal, 58(5), 1501-1511.https://doi.org/10.2136/sssaj1994.03615995005800050033x

Chapman, H.D. (1965). Cation exchange capacity. In, C.A. Black, L.E. Ensminger and F.E.Clark (Eds). Methods of soil analysis. Agronomy, 9, 891-901. American Society of Agronomy., Inc., Madison, Wisconsin.

Denton, O.A., Aduramigba-Modupe, V.O., Ojo, A.O., Adeoyolanu, O.D., Are, K.S., Adelana, A.O., Oyedele, A.O., Adetayo, A.O. \& Oke, A.O., (2017). Assessment of spatial variability and mapping of soil properties for sustainable agricultural production using geographic information system techniques (GIS). Cogent Food \& Agriculture, 3, 1279366https://doi.org/10.1080/23311932.2017.1279366

Esu, I. E. (2005). Characterization, classification and management problems of the major orders in Nigeria. $26^{\text {th }}$ Inaugural Lecture, Department of Soil Science University of Calabar, 38-59.

Fasina, A. S., Omolayo, F. O., Ajayi, O. S. \& Falidun, A. A. (2007). Influence of land use on soil properties of three mapping Units in Southwestern Nigeria. implications for sustainable soil management. Medwell Online Agriculture Journal, 2(3), 879-883.

Franzen, D. W. \& Peck, T. R.1 (995). Field soil sampling density for variable rate fertilization. Journal of Production Agriculture, 8(4), 568-574.https://doi.org/10.2134/jpa1995.0568

González I, Neaman A \& Rubio P, Cortés A (2014). Spatial distribution of copper and pH in soils affected by intensive industrial activities in Puchuncaví and Quintero, central Chile. J Soil Sci Plant Nutr, 14, 943-953.https://doi.org/10.4067/S0718-95162014005000074

Goovaerts, P. (1998). Geostatistical tools for characterizing the spatial variability of microbiological and physico-chemical soil properties. Biol Fertil Soils, 27, 315-334. https://doi.org/10.1007/s003740050439

Goovaerts, P. (1999).Geostatistics in soil science, state-of-the-art and perspectives. Geoderma, 89, 1-45https://doi.org/10.1016/S0016-7061(98)00078-0

Gouri S. B., Pravat K. S. \& Rabindranath C. (2018). Assessment of spatial variability of soil properties using geostatistical approach of lateritic soil (West Bengal, India). Annals of Agrarian Science, 16, 436-443.https://doi.org/10.1016/j.aasci.2018.06.003

Hengl T, Rossiter DG \& Stein A (2004) Soil sampling strategies for spatial prediction by correlation with auxiliary maps. Aust J Soil Res, 41(8), 1403-1422.https://doi.org/10.1071/SR03005

Heuvelink GBM \& Webster R (2001) Modeling soil variation, past, present, and future. Geoderma, 100(3-4), 269-301 https://doi.org/10.1016/S0016-7061(01)00025-8

Imadojemu, P. E., D. N. Osujieke, S. N. Obasi, J. O. Mbe \& E. G. Dibofori (2018). Characterization and classification of some soils of Edo State formed under different parent materials. FUW Trends in Science \& Technology Journal, 3(1), 201-206.

Jenny, H (1941). Factors of soil formation; a system of quantitative Pedology (pp. 281) 1st Edition., McGraw-Hill book company, inc., New York, London. 
Johnston, K. Ver Hoef, J. M. Krivoruchko, K. \& Lucas, N. (2001). Using ArcGis Geostatistical Analyst. ESRI, 300

Kerry G. (2012). Uplift, denudation, and their causes and constraints over geological timescales. ScienceDirect Pages, 608-644 https://doi.org/10.1016/B978-0-444-53042-4.00022-4

Kingsley John, Ackley U. Akpan-Idiok (2019). Land evaluation, characterization and classification of soil for the proposed oil palm plantation in Ekpri Ibami, Akamkpa Local Government Area, Nigeria. International Journal of Environment, Agriculture and Biotechnology (IJEAB), 4(3), 621-634, https://doi.org/10.22161/ijeab/4.3.6

Lin H, Wheeler D, Bell J \& Wilding L (2005). Assessment of soil spatial variability at multiple scales. Ecol Model, 182, 271-290 https://doi.org/10.1016/j.ecolmodel.2004.04.006

Mabit L \& Bernard C. (2007). Assessment of spatial distribution of fallout radionuclides through geostatistics concept. Journal of Environmental Radioactivity, 97, 206-219.https://doi.org/10.1016/j.jenvrad.2007.05.008

McBratney, A.B., Odeh, I.O.A., Bishop, T.F.A., Dunbar, M.S. \& Sha tar, T.M. (2000). An overview of pedometric techniques for use in soil survey. Geoderma, 97, 293-327.https://doi.org/10.1016/S0016-7061(00)00043-4

Moasheri, S. A. \& Foroughifar, H. (2013). Estimation of the values of soil absorption ratio using integrated geostatistical and artificial neural network methods. International Journal of Agriculture and Crop Sciences, $5(20), 2423$.

NIFOR. (2013). Weather data (Temperature, Rainfall, Relative Humidity), Nigeria Institute For Oil Palm Research Main Station, Benin-City, Nigeria. 110p.

Ofem, K. I., Ediene, V. F., John, K. \& Akpan-Idiok, A. U. (2017). Spatial Variability Of Soil Properties In Yakurr Local Government Area, Southeast Nigeria. Asian Journal of Plant and Soil Science, 2(1), 6-16.

Olsen, S.R., C.V. Cole, F.S. Watanable \& L.A. Dean (1954). Estimation of avariable phosphorus in soil by extraction with sodium bicarbonate. USDA Circular, 939, 1-19

Penížek, V. L. Borůvka (2006). Soil depth prediction supported by primary terrain attributes, A comparison of methods Plant Soil Environ, 52(9), 424-430https://doi.org/10.17221/3461-PSE

Pravat, K. S., Gouri, Bhunia, S. \& Ramkrishna, M (2016). Spatial analysis of soil properties using GIS based geostatistics models. Model. Earth System and Environment, 2, 107 https://doi.org/10.1007/s40808-016-0160-4

Reza, S.K., D.C. Nayak, T. Chattopadhyay, S. Mukhopadhyay, S.K. Singh \& R. Srinivasan (2015). Spatial distribution of soil physical properties of alluvial soils, a geostatistical approach, Archives of Agronomy and Soil Sciencehttps://doi.org/10.1080/03650340.2015.1107678

Safari Y, Boroujeni I.E, Kamali A, Salehi MH \& Bodaghabadi MB (2013). Mapping of the soil texture using geostatistical method (a case study of the Shahrekord plain, central Iran). Arab J Geosci, 6, 3331-3339.https://doi.org/10.1007/s12517-012-0559-9

Shibu M, Leffelaar P, Van Keulen H \& Aggarwal P (2006). Quantitative description of Soil organic carbon matter dynamics - a review of approaches with reference to rice-based cropping systems. Geoderma, 137, 1-18https://doi.org/10.1016/j.geoderma.2006.08.008

Shukla, P.K. (2009). Nutrient dynamics of teak plantation and their impact on soil productivity. A case study from India. Proceeding of the $8^{\text {th }}$ World Forestry Congress, Oct.18-23, Buenos Aires, Argentina, 1-11.

Townsend, A. R., Vitousek, P. M. \& Trumbare, S. E. (1995). Soil organic matter dynamics along gradients in temperature and land use on the Island of Hawaii. Ecology, 76, 721-733.https://doi.org/10.2307/1939339

Van Reeuwijk, L.P. (1992). Procedures for soil analysis, 3rd Ed. International Soil Reference and Information Center (ISRIC), Wageningen, the Netherlands. 34

Walkley, A. \& I.A. Black. (1934). An examination of the method for determining Soil organic matter and proposed modification of the chromic acid titration method. Soil Science Society of America Proceedings, 63, 257.https://doi.org/10.1097/00010694-193401000-00003

Wang, MJ YQ \& Shao MA (2013). Spatial variability of soil physical properties in a region of the Loess Plateau of PR China subject to wind and water erosion. Land Degrad Dev, 24(3), 296-304https://doi.org/10.1002/ldr.1128 
Wang, Y., Zhang, X. \& Huang, C. (2009). Spatial variability of soil total nitrogen and soil total phosphorus under different land uses in a small watershed on the Loess Plateau, China. Geoderma, 150(1), 141-149.https://doi.org/10.1016/j.geoderma.2009.01.021

Webster, R. \& Oliver, M. A. (2007). Geostatistics for environmental scientists, John Wiley \& Sons.https://doi.org/10.1002/9780470517277

Weller, U., Castell, W.Z., Sommer, M. \& Wehrhan, M. (2002). Kriging and Interpolation with Radial Base Functions a Case Study.

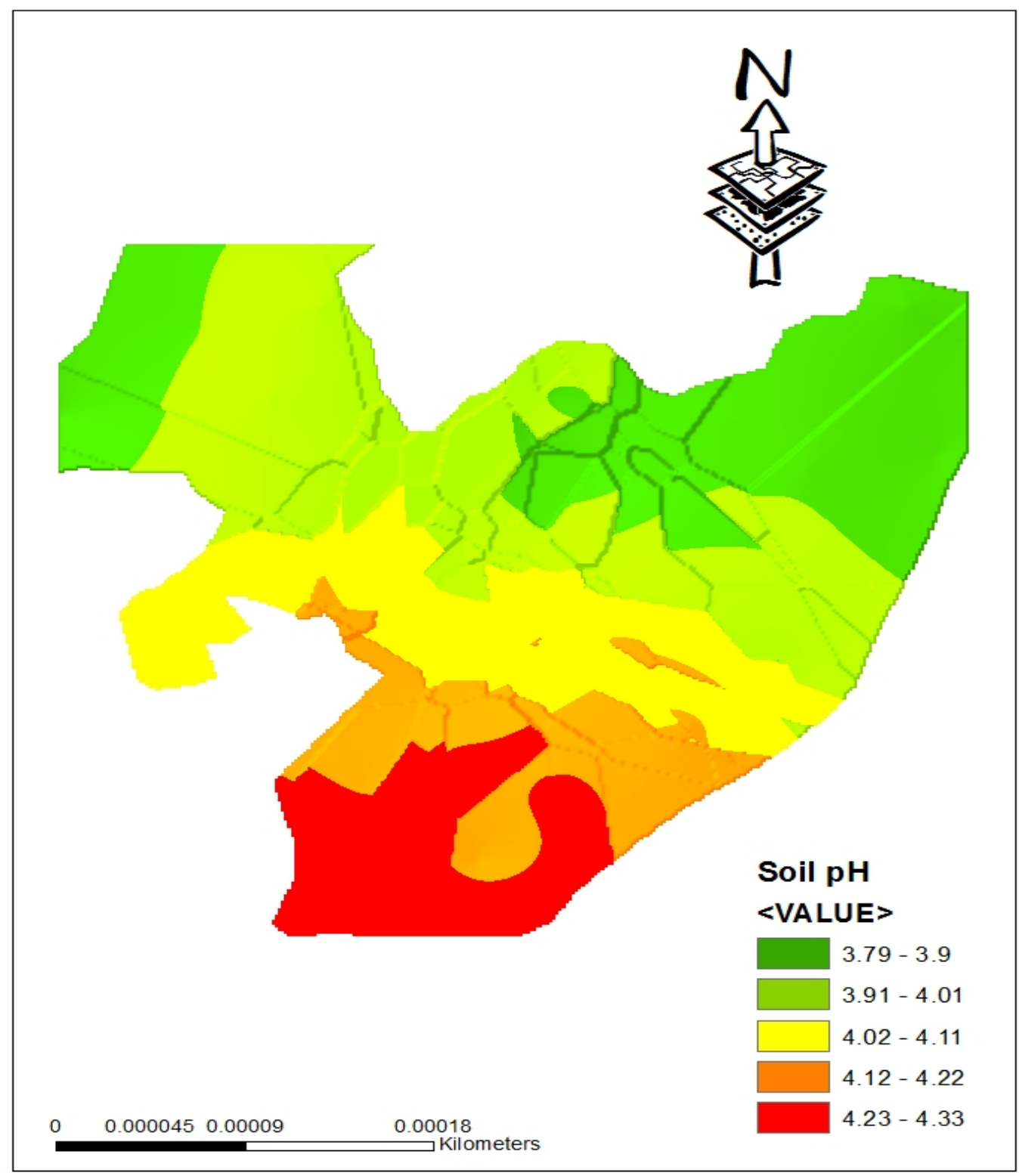

a. Soil $\mathrm{pH}$ 


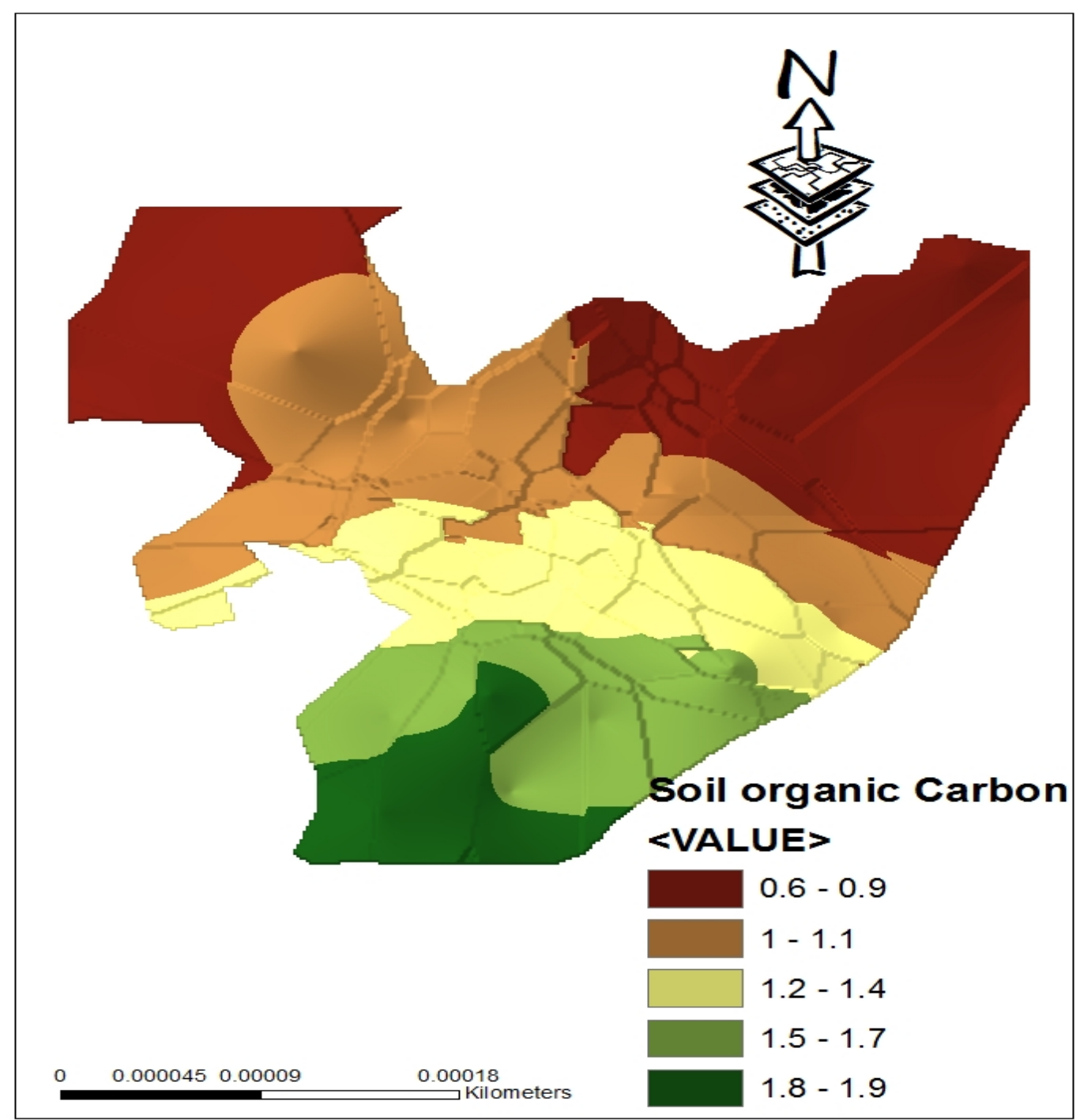

b. Soil organic carbon 


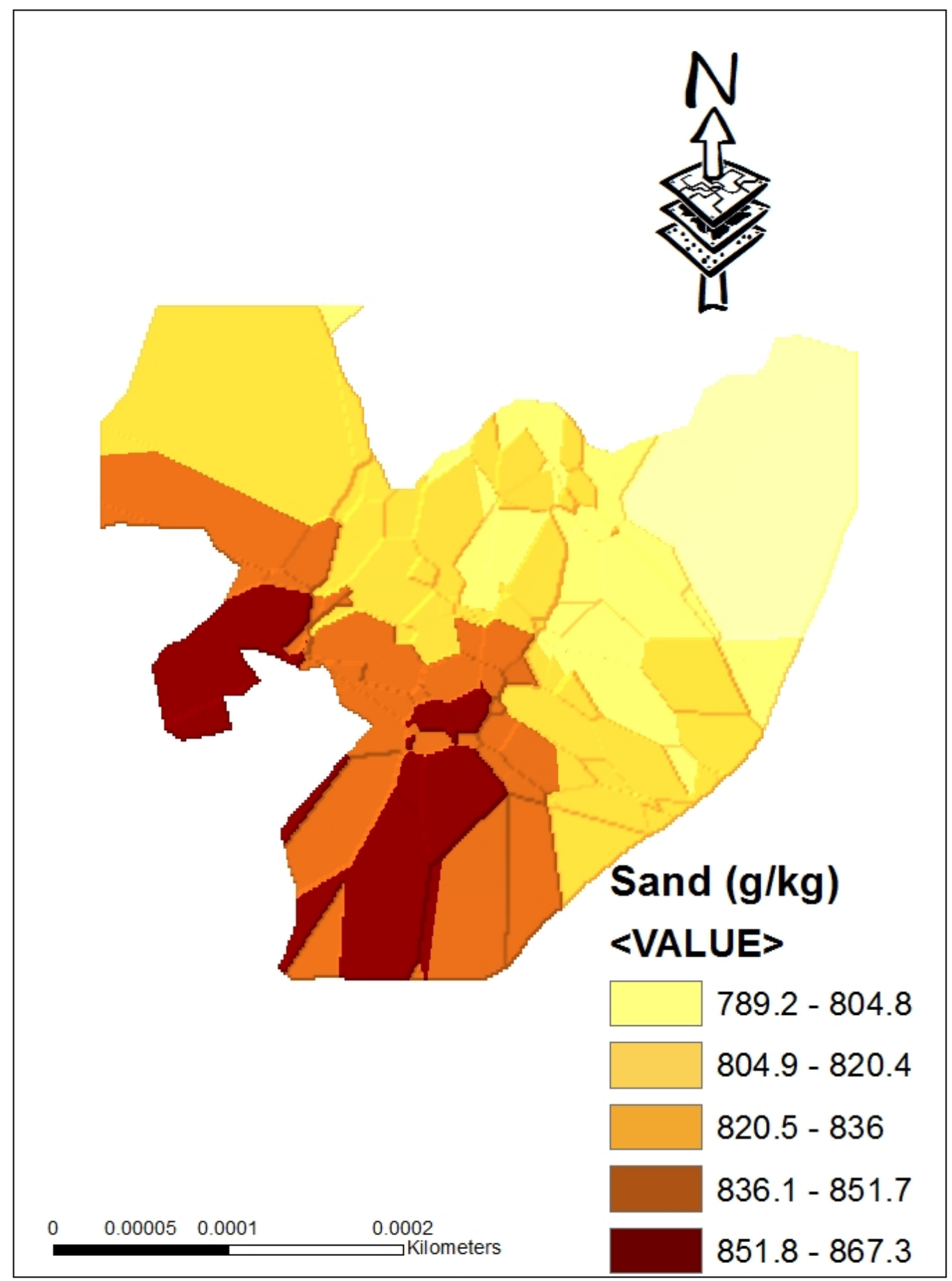

c. Sand 


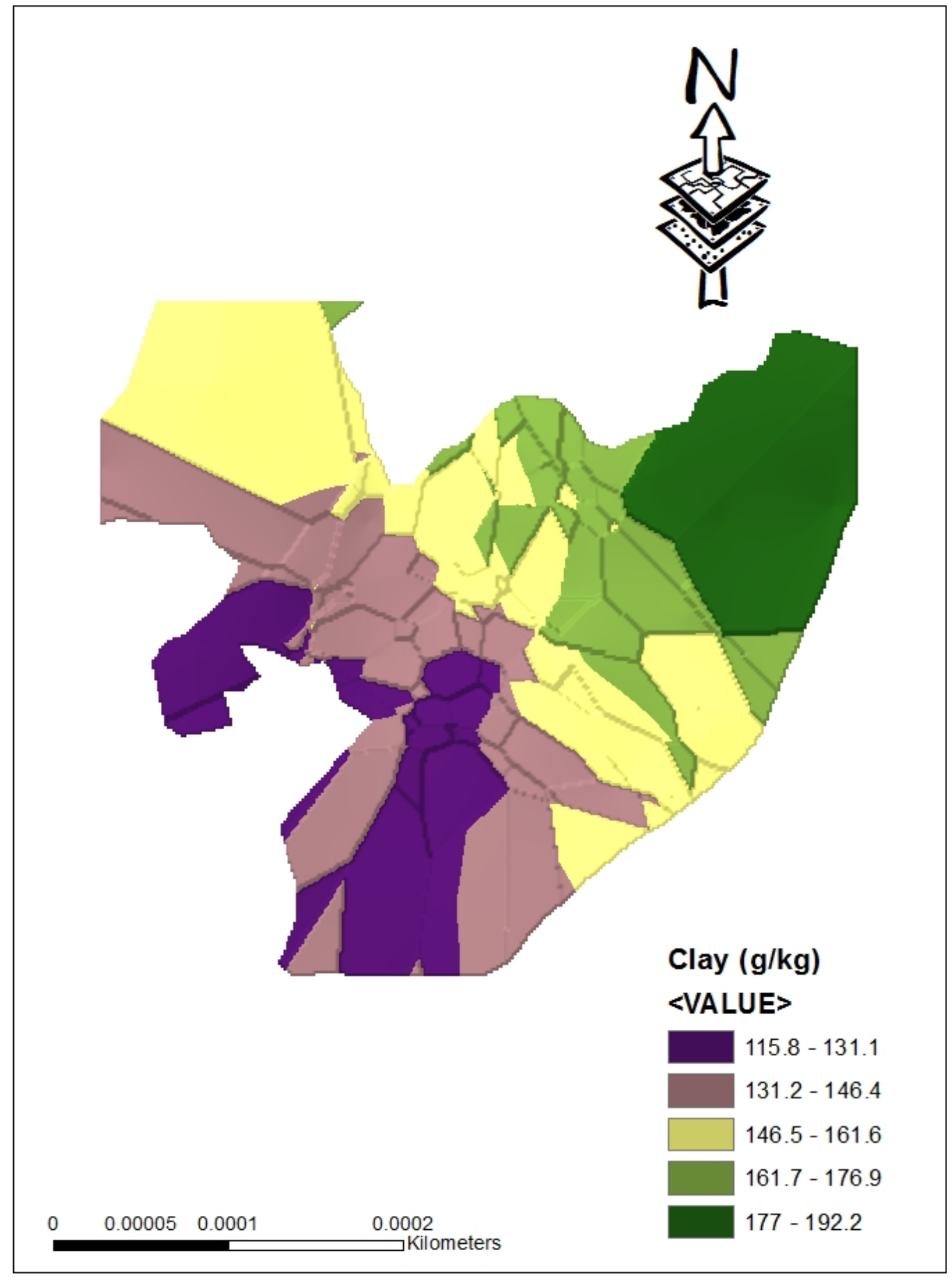

d. Clay 


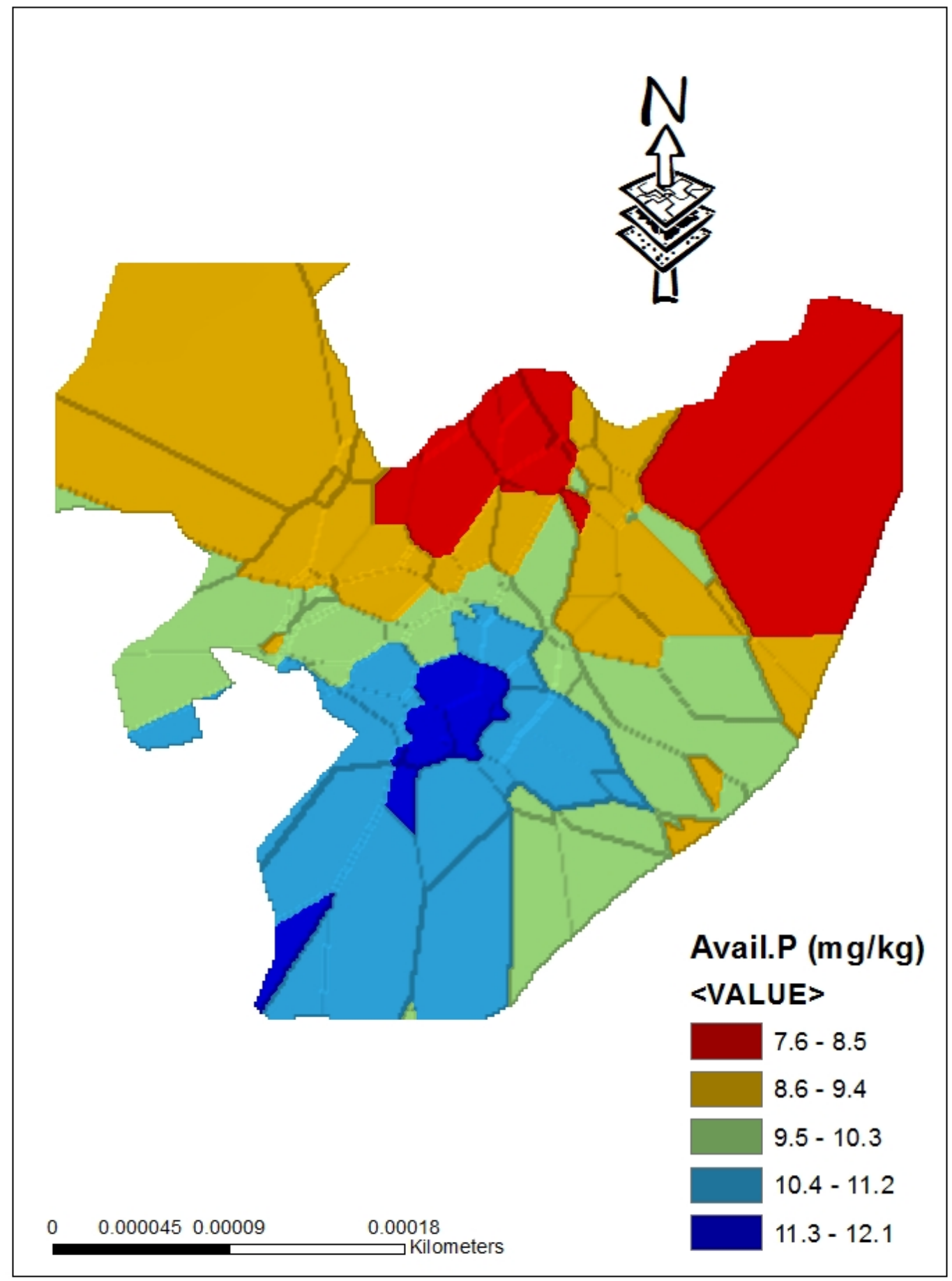

e. Available 


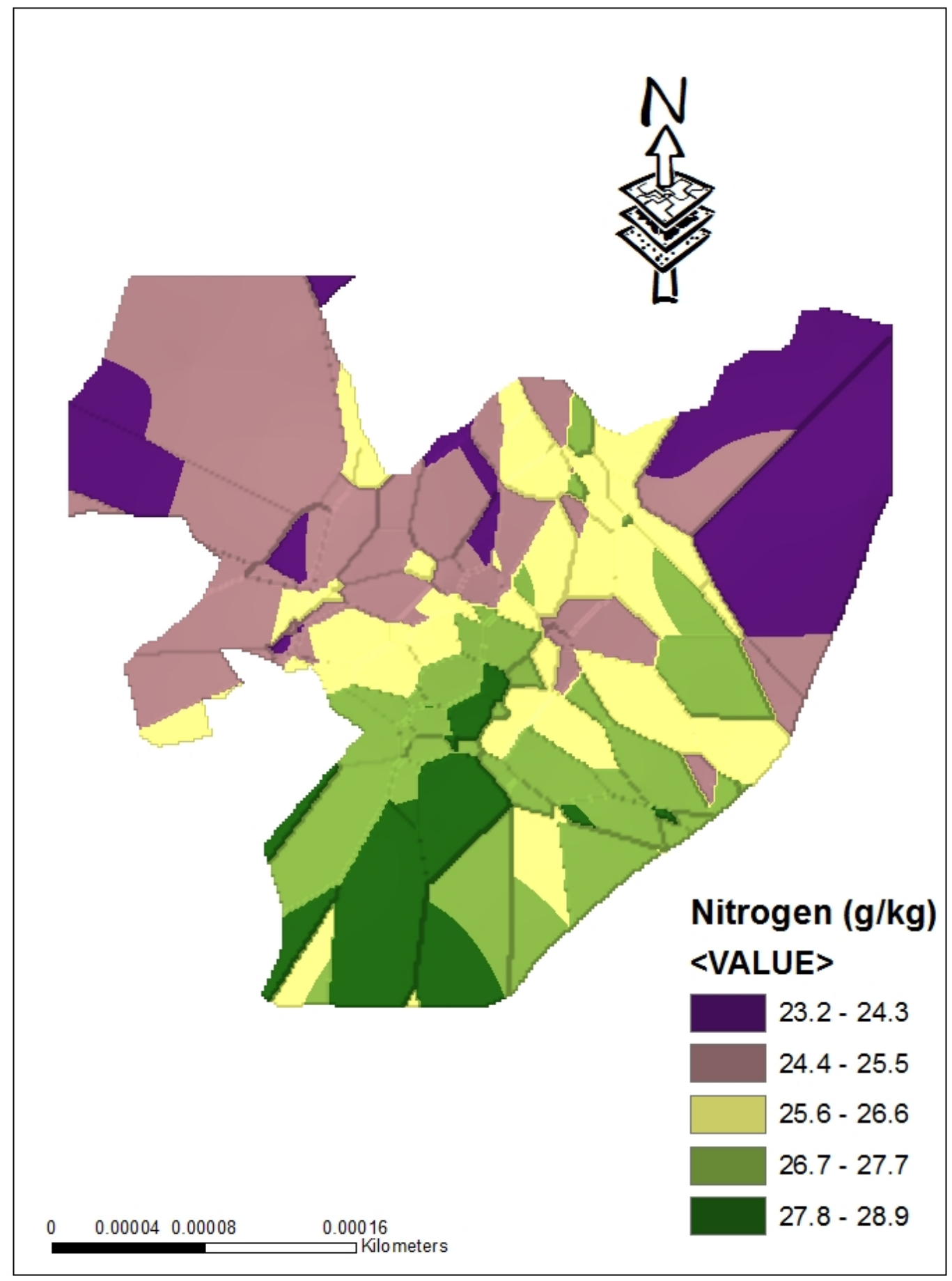

f. Nitrogen 


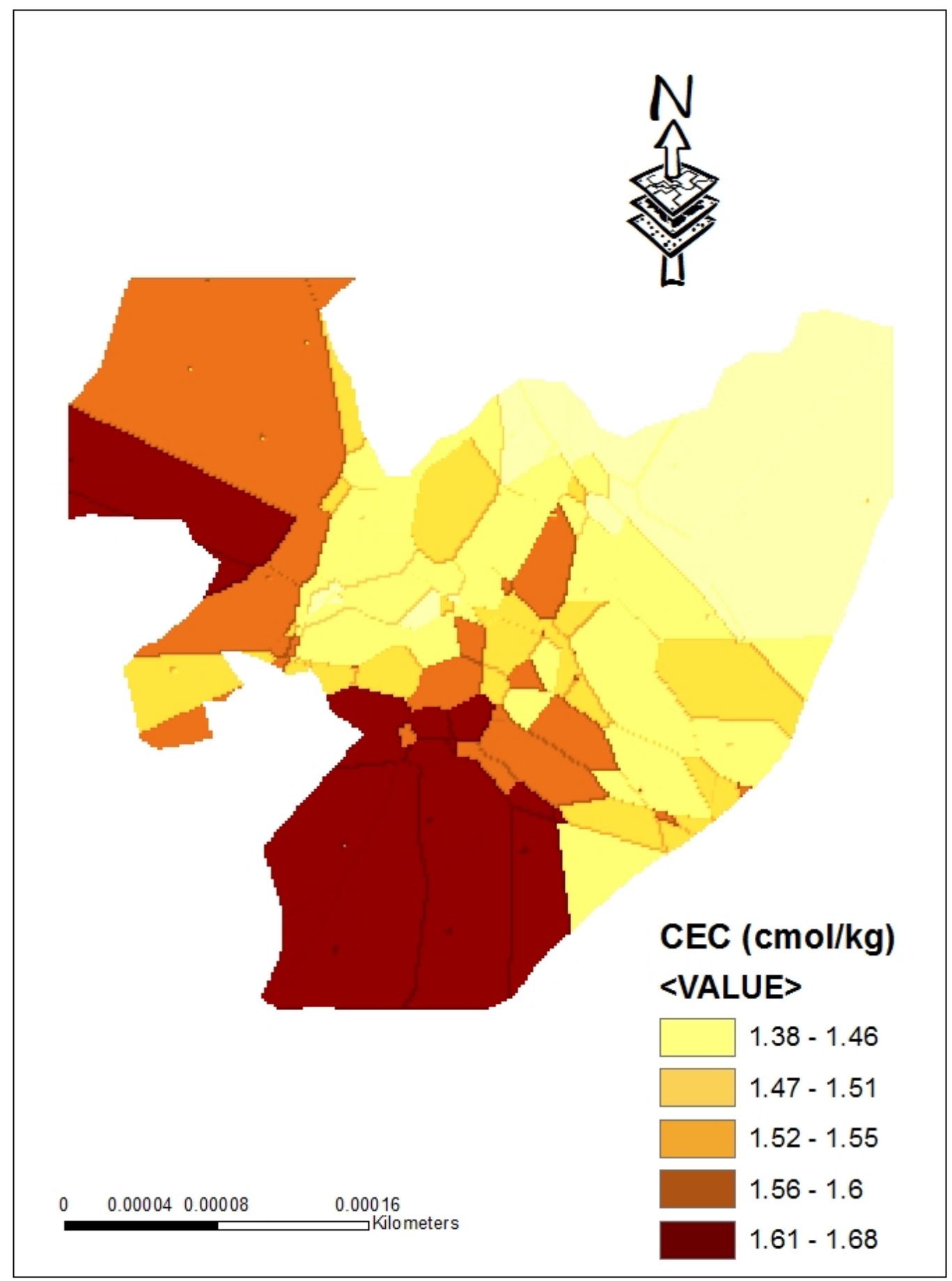

g. Cation exchange capacity

Figure 1. 


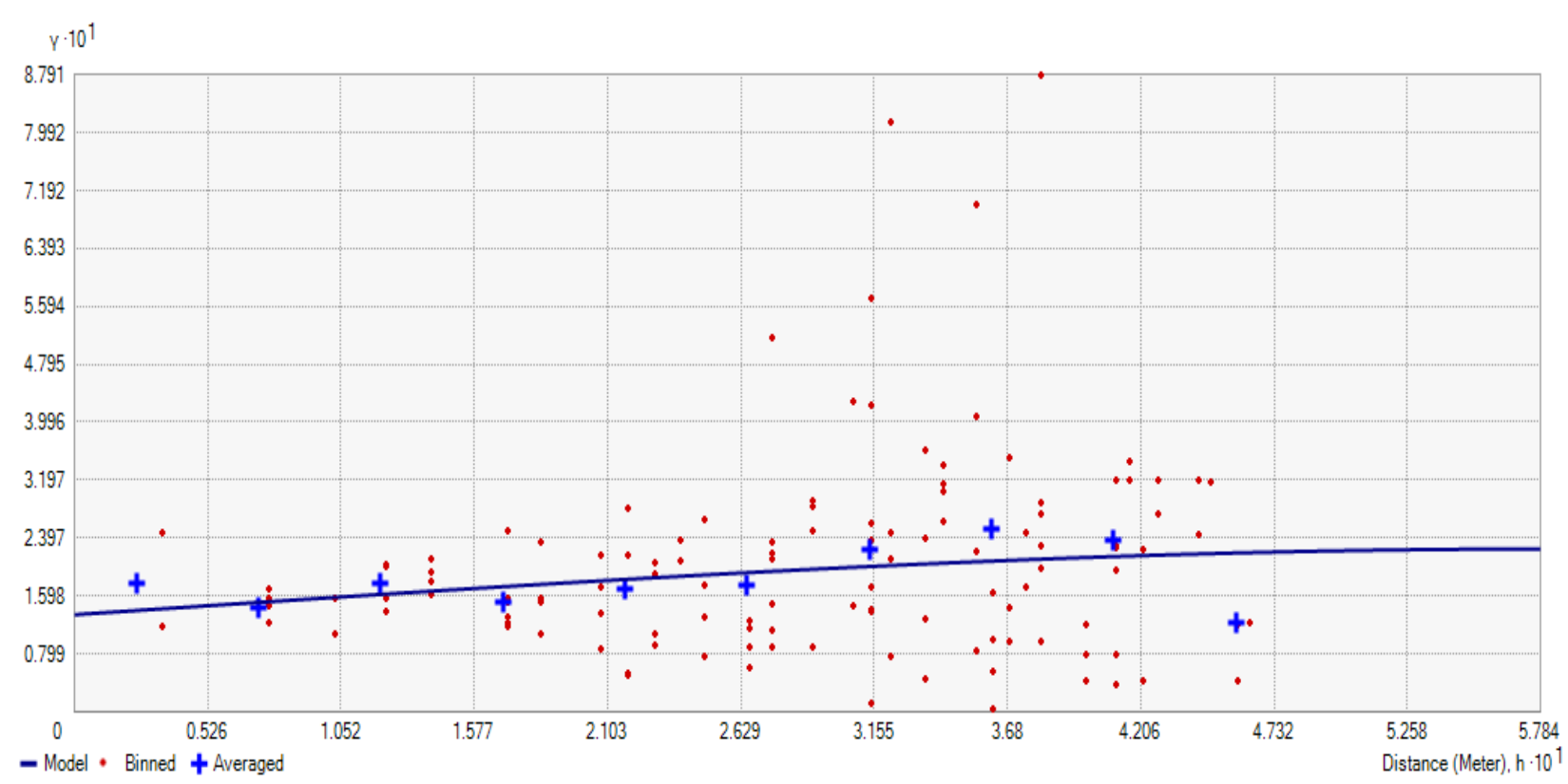

a. $\mathrm{pH}$

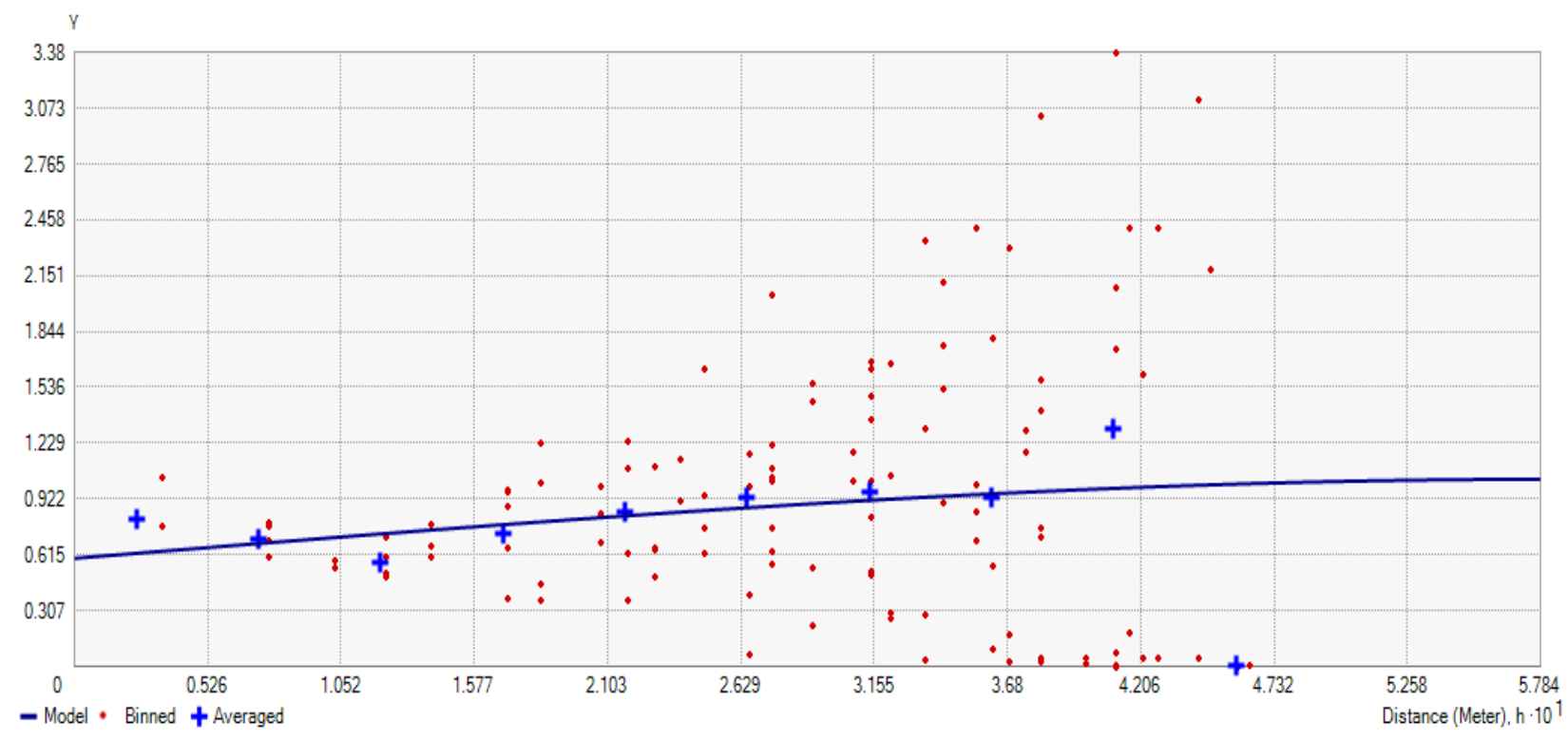

b. $\mathrm{SOC}$ 

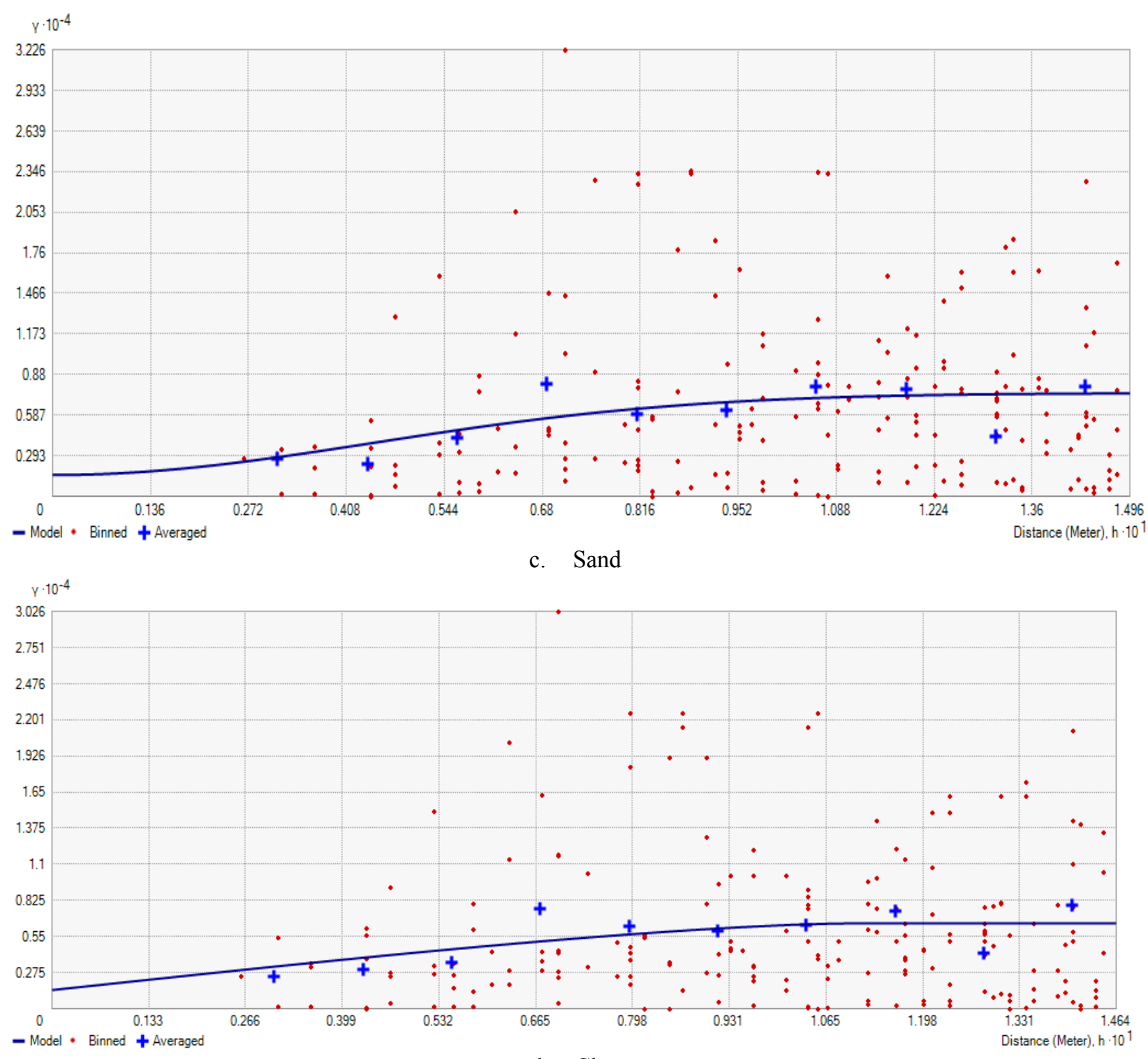

d. Clay

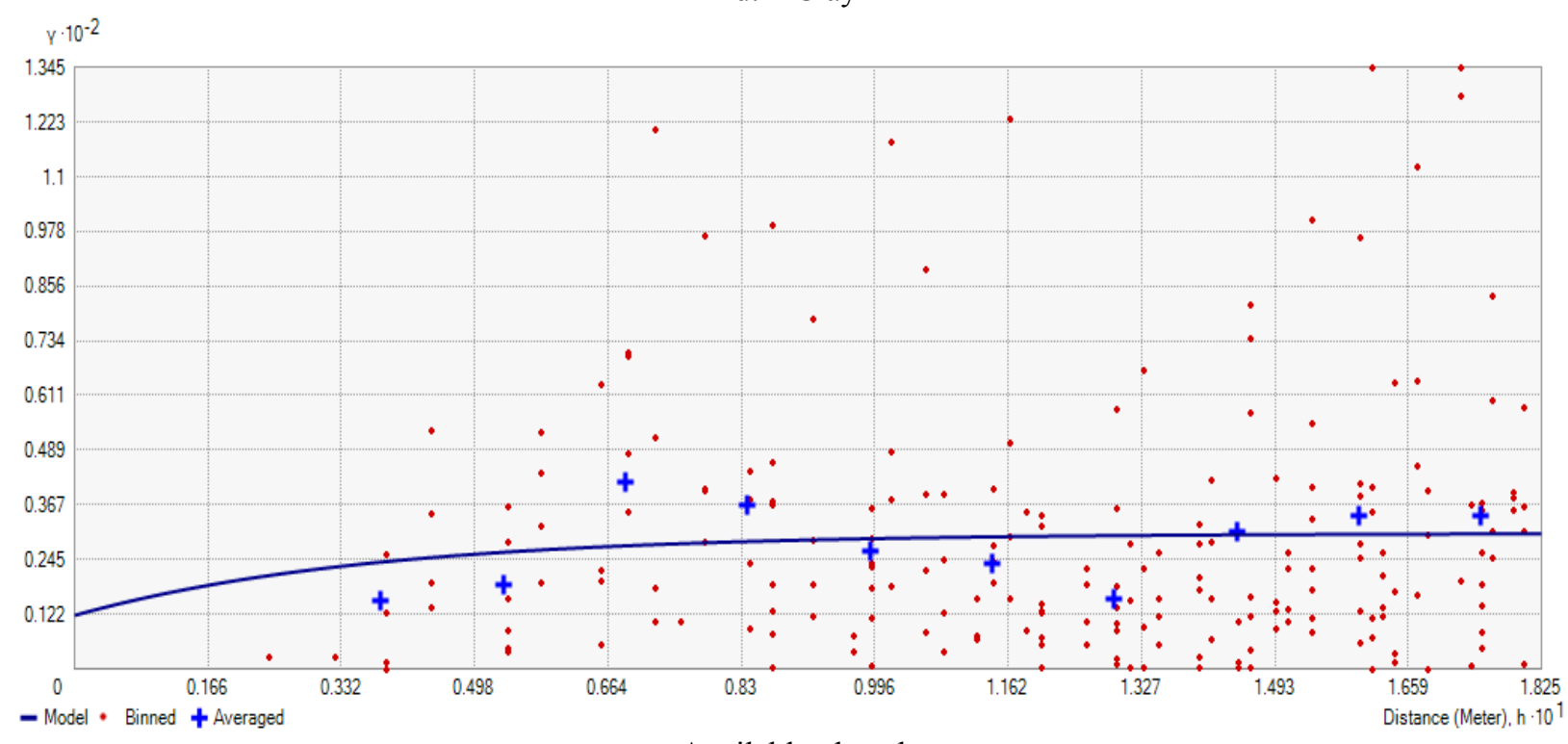

e. Available phosphorus 

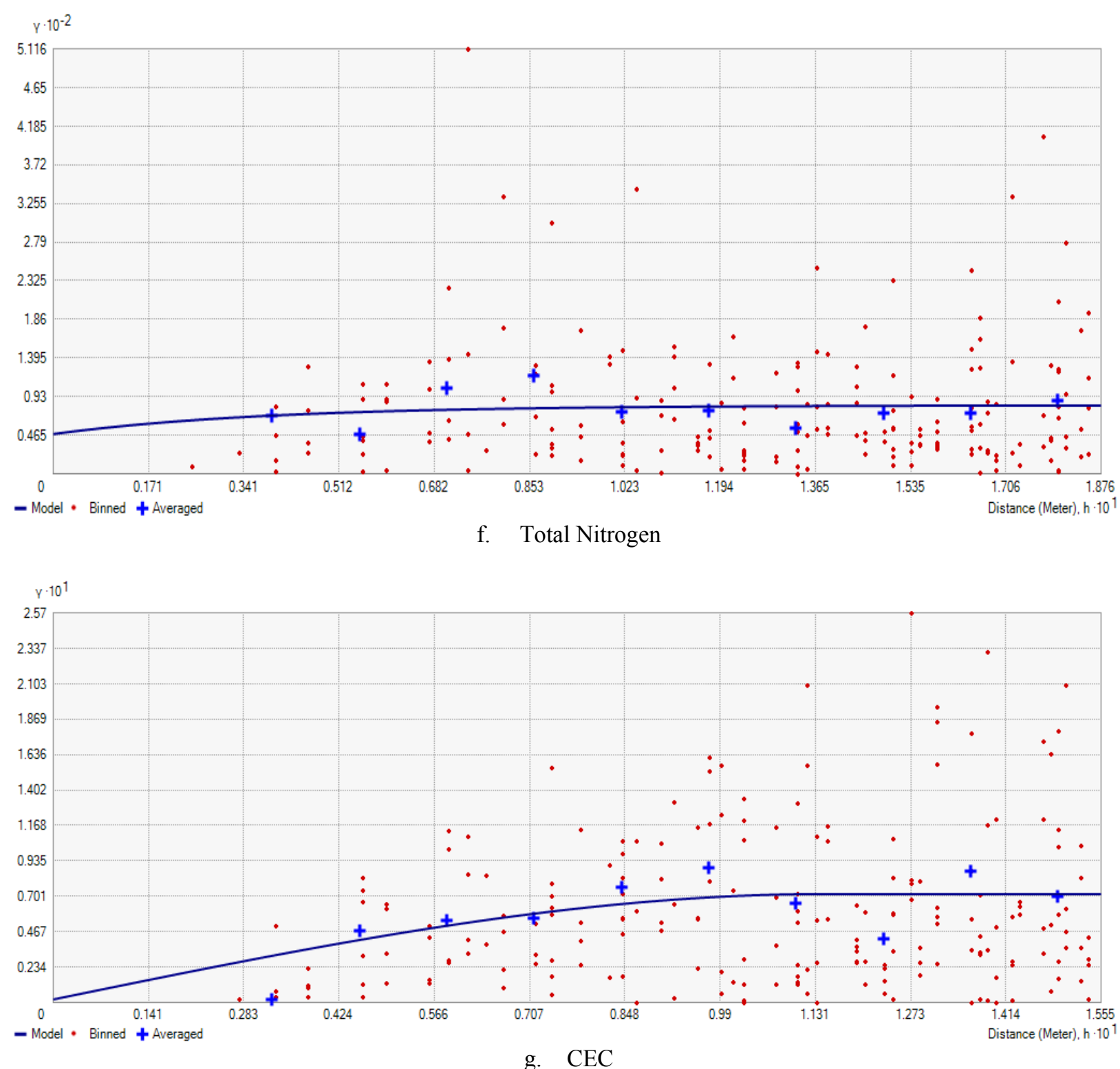

Figure 2. semivariograms for soil pH, SOC, Sand, Clay, Available Phosphorus, Total Nitrogen and CEC

\section{Copyrights}

Copyright for this article is retained by the author(s), with first publication rights granted to the journal.

This is an open-access article distributed under the terms and conditions of the Creative Commons Attribution license (http://creativecommons.org/licenses/by/4.0/). 